\title{
Interactive comment on "Spatial and temporal analysis of fatal off-piste and backcountry avalanche accidents in Austria with a comparison of results in Switzerland, France, Italy and the United States" by Christian Pfeifer et al.
}

\section{Anonymous Referee \#1}

Received and published: 2 December 2016

The authors explore trends in the annual number of backcountry avalanche fatalities in Austria and compare these to four other countries. The temporal analysis is carried out applying a generalized additive model. The study evaluates whether linear or non-linear functions describe the annual fatality data best. Additionally, maps showing the spatial distribution of avalanche fatalities by municipality in Austria are presented. These are the novel aspects of the presented work. The topic of the study is within the scope of the journal and will likely be of interest to the journals audience.

Printer-friendly version

Discussion paper 


\section{General comments}

I would like to address two main issues concerning the manuscript: (1) the insufficient discussion of the results and embedding of the study within the context of current research, and (2) the time-period analyzed.

(1) Concerning the first point, potentially relevant studies are mentioned in the detailed comments below.

(2) The most recent five years (2011/12 - 2015/16) were not considered in this analysis. However, their inclusion would greatly increase the currency of the analysis. This seems particularly important, as the authors suggest avalanche prevention measures in their study (abstract and lines 282-286). Extending the data-set until 2015/16 would allow a comparison to results shown in recent publications, in which (not significantly) increasing backcountry avalanche fatality numbers were noted during the most recent years (e.g. United States (Birkeland, 2016) and European Alps (Techel et al., 2016)). Therefore, I strongly recommend to include these years, not just for Austria, but also for the other countries.

\section{Detailed comments, by section}

\section{Abstract}

I. 29: The study addresses backcountry avalanche fatalities, not avalanche fatalities as written.

I. 30-31: There are numerous studies which showed that the backcountry and out-of-bounds avalanche fatality numbers are not constant (e.g. France (Jarry, 2011, Fig. 3); Switzerland (Harvey and Zweifel, 2008); United States (Page et al., 1999); Italy (Valt and Pivot, 2013); European Alps, France, Austria, Switzerland, Italy: (Techel et al., 2016)).

Printer-friendly version

Discussion paper
Interactive

comment

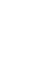




\section{Introduction}

I. 43-44: specify the "various" reasons which are of special public interest.

I. 47-48: additionally to Brugger et al. (2001), more recent publications should be investigated whether this statement is still considered true (see also the beforementioned references concerning the abstract)

I. 52: not clear how the citation of Ammann, 2001 is related to the statement by Harvey and Zweifel (2008)

I. 53-55: additionally, in their annual reports the Österreichische Lawinenwarndienste (2016) provide a 20-year overview of the avalanche fatalities in Austria (e.g. Fig. 4, p. 33 in the 2016 report)

I. 66-69: there are brief summaries showing long-term trends of Austrian backcountry fatality statistics in the book by Höller (p. 91, 2015) and also in the 2016 report of the Österreichische Lawinenwarndienste (2016) (pages 210 and 211, results based on Techel et al. (2016))

\section{Data and methods}

I. 105-111: It should be mentioned, when and how the ICAR data was accessed (URL or citation). It is unclear which of the mentioned ICAR fatality categories were used in the analysis.

I. 117-118 and I. 129-130: I find this very difficult to understand. Did you calculate the trend for each municipality (aggregating the data in terms of location, I. 117-118) separately and then aggregate it again for the regional analysis? Or did you use the annual fatality numbers (all of Austria) for the trend analysis, and the total number of fatalities for each municipality? Please explain this more clearly.

I. 125: You state that in your "opinion" AIC and BIC are better criterion than reporting p-values. You should explain why using AIC and BIC would be more appropriate (advantages, disadvantages). Possibly, you could also give a reference. 


\section{Results and Discussion}

The results section refers to the graphs and tables, but does not present any data. Data is presented mostly in the discussion section. The results should be discussed in more depth than is currently the case.

Trend analysis

The advantage and disadvantage of the proposed statistical approach should be discussed, as this is the main methodological novelty compared to previous publications exploring avalanche fatality statistics. In particular, the following points might be of interest to the reader:

- To what extent do single (or a cluster of) winters with many (or very few) fatalities influence the trend lines shown?

- In your analysis, you analyze subgroups of the data (e.g. off-piste fatalities only). One of the arguments Techel et al. (2016) considered relevant for combining national fatality statistics was the assumption that single multi-fatality events and/or years with many fatalities potentially could have a large effect on trend statistics. Please discuss to what extent this may be relevant, in particular for the trend calculation of the off-piste subgroup, which are characterized by even fewer incidents per year. Please explain whether relatively small accident numbers could be a reason for the sometimes highly fluctuating trend lines (you already briefly comment on this for the Austrian data on lines 193-194).

- The $90 \%$ confidence intervals shown in the figures is large at the beginning/end of the time-series. This highlights the greater uncertainty of the trend line calculation. Readers not familiar with confidence intervals, might miss this point when looking at the figures. Therefore, I propose to discuss these uncertainties in the
Interactive

comment

Printer-friendly version

Discussion paper 
text.

- Often, the $90 \%$ confidence band is relatively wide, which raises the question whether the reported trends can be interpreted as statistically significant. For instance, the trend line of the Swiss off-piste fatalities drops in the nineties and rises in the 2000's. However, the max of the confidence interval in the 1990's is about as high as the minimum in 2000 . Therefore, I wonder if the peak around the year 2000 can be considered statistically significant. I recommend you show which of the trends are statistically significant.

You show in Table 2 that the non-linear model is preferable for all the European countries (except for Austrian off-piste fatalities). This is a main result of the study. However, I suggest you discuss potential reasons for the Austrian off-piste fatality trend line being linear, when all the other European trend lines are non-linear.

The trend line for the Swiss backcountry fatalities (Fig. 3) drops from almost 30 in $1983 / 84$ to approximately 15 in the mid-1990's (Fig. 3). This seems like a very strong decrease and is in contrast to the slight but not significant decrease shown/described for the 1990's (e.g. Fig. 3 in SLF (2016) or in Techel et al. (2016)).

On lines 186 to 194 you note a peak in the fatality numbers for Austria in the 1980's, and conclude that higher precipitation during these years might explain this. Looking at off-piste fatalities only, you do not note this peak for Austria. These two statements seem contradictory. It may also be of interest that several authors noted increased numbers of recreational avalanche fatalities in years with less snow (e.g. Luzian, 2000; Valt et al., 2009; Valt and Cianfarra, 2012).

Printer-friendly version

Regional analysis

The regional analysis showed spatial clusters in two regions (Arlberg and Sölden, Fig. 
7 and 8). However, an in-depth discussion of potential reasons for these hot-spots is lacking. For instance, visually comparing the clusters shown in Fig. 8 to the size and spatial distribution of ski resorts in Austria (map in Fig. 1 and list of top 20 winter sport municipalities in Fleischhacker (2016)), seems to indicate that these clusters correlate to the spatial distribution of ski resorts in Austria (and hence a greater number of recreationists riding off-piste?). Even though Fuchs et al. (2015) explored the spatial distribution of houses and residents exposed to snow avalanches, the spatial pattern looks again similar to those in Fig.s 7 and 8. with the highest density in the Arlberg and southern Tirol regions.

In general, I would consider it benefitial if you could include other relevant parameters in the spatial analysis. For instance, the spatial clusters of off-piste fatalities could be compared to the distribution and size of the ski areas in the municipalities in Austria (e.g. the data behind the map in Fleischhacker (2016)), while calculating the density of fatalities per surface area above a critical elevation might show if these clusters are related to Alpine topography (e.g. in a Swiss study Techel et al. (2015) considered the elevation range where more than $95 \%$ of the recreational accidents occurred).

In the methods section (lines 143-147) you describe the use of Markov random fields to identify the regional hot spots. In the results section and Fig. 7 and 8 , it remains unclear how this method was used and what results were obtained. Please highlight what results were gained using this method.

On lines 262-264 you state that you cannot compare spatial patterns to other countries due to lack of information. However, at least for some countries or regions, spatial patterns have been explored and explanations for clusters were given. Relevant publications might include Spencer and Ashley (2010, for the western United States), Logan and Witmer (2012, for Colorado) or Techel et al. (2015, for Switzerland). While Spencer and Ashley argued that these clusters are the areas with the highest concentration of winter sport activities, Logan and Witmer showed that most accidents occurred in areas which are highly accessible (closeness to roads). Techel et al.

Printer-friendly version

Discussion paper 
concluded that a higher risk to be involved in a backcountry avalanche accident was also correlated to regions with a more frequent shallow snowpack and persistent weak layers. These were not always the regions with the highest number of fatalities.

\section{Conclusion}

I. 287-297: It is indeed difficult to verify the influence of increased numbers of recreational activity in winter backcountry. The study by Fleischhacker (2016) might provide a suitable reference indicating trends observed in Austrian winter sport regions. A recent study by Winkler (2016, in German) or Winkler et al. (2016, in English) has explored the trends in the number of winter backcountry users in Switzerland during the last two decades. Potentially, this study may be of interest when discussing backcountry usage trends.

\section{Figures}

\section{Fig. 1 and 2:}

The caption should mention that a $90 \%$-confidence interval is shown. Grid lines would be helpful.

\section{Fig. 3 to 6:}

The $x$-axis labeling of the right plot (off-piste) is difficult to read. Maybe leave some space between the plots.

The caption should mention that a $90 \%$-confidence interval is shown.

Printer-friendly version Grid lines would be helpful.

All these figures, and possibly also the Austrian data for the years 1983/84 until $2010 / 11$ could be presented in a panel plot with the same axis-limits for all countries. 
This would facilitate the comparison between the different time-series.

Fig. 7 and 8:

The color choice is difficult to read for colorblind readers. I suggest using any of the color schemes proposed e.g. by Brewer (1994); Neuwirth (2014); Zeileis et al. (2009). Because most readers will be unfamiliar with the Austrian Alps, a map showing the mountainous areas relevant for avalanching - for instance the surface area above $1500 \mathrm{~m}$ - would be helpful for comparison.

\section{References}

Birkeland, K.: U.S. avalanche fatality trend is flat for the past 22 seasons, http://www.fsavalanche.org/news/2016/6/27/ us-avalanche-fatality-trend-is-flat-for-the-past-22-seasons, last access 01.12.2016, 2016.

Brewer, C.: Color use guidelines for mapping, Visualization in modern cartography, pp. 123148, 1994.

Brugger, H., Durrer, B., Adler-Kastner, L., Falk, M., and Tschirky, F.: Field management of avalanche victims, Resuscitation, 51, 7-15, doi:10.1016/S0300-9572(01)00383-5, 2001.

Fleischhacker, V.: Aktuelle Nachfragetrends im Wintersporttourismus in Österreich, Tech. rep., Institut für touristische Raumplanung ITR, Tulln an der Donau, http://netoffice.salzburgerland. com/downloads/salzburgerland_aktuell/0916\%20Studie-Trends-im-Witnersporttourismus. pdf, last access 01.12.2016, 2016.

Fuchs, S., Keiler, M., and Zischg, A.: A spatiotemporal multi-hazard exposure assessment based on property data, Natural Hazards and Earth System Sciences, 15, 2127-2142, doi: 10.5194/nhess-15-2127-2015, http://www.nat-hazards-earth-syst-sci.net/15/2127/2015/, 2015.

Harvey, S. and Zweifel, B.: New trends of recreational avalanche accidents in Switzerland, in: Proceedings International Snow Science Workshop 2008, Whistler, Canada, pp. 9-15, 2008. Höller, P.: Lawinen - die grössten Katastrophen in Österreich seit 1946/47, Studia Universitätsverlag Innsbruck, 95p., 2015. 
Jarry, F.: 40 ans d'accidents d'avalanche ... 40 ans de prévention, Neige et Avalanches, 135, 18-22, 2011.

Logan, S. and Witmer, F.: Spatial, temporal, and space-time analysis of fatal avalanche accidents in Colorado and the United States, 1991 to 2011, in: Proceedings International Snow Science Workshop, Anchorage, Alaska, USA, pp. 479-486, http://arc.lib.montana.edu/ snow-science/objects/issw-2012-479-486.pdf, 2012.

Luzian, R.: Lawinenschäden in Österreich in der Periode von 1967/68 bis 1992/93, in: Proceedings Interpraevent 2000, Villach, Austria, pp. 437-450, 2000.

Neuwirth, E.: RColorBrewer: ColorBrewer Palettes, https://CRAN.R-project.org/package= RColorBrewer, $r$ package version 1.1-2, 2014.

Österreichische Lawinenwarndienste: Winterberichte, https://lawine.tirol.gv.at/archiv/ winterberichte/, last access: 01.12.2016, 2016.

Page, C., Atkins, D., Shockley, L., and Yaron, M.: Avalanche deaths in the United States: a 45-year analysis, Wilderness Environ Med., 10, 146-151, 1999.

SLF: Lawinen in der Schweiz: Entwicklung in den letzten 80 Jahren, http://www.slf.ch/ praevention/lawinenunfaelle/Publikationen/lawinenunfaelle/Spezialthemen/unfaelle_80jahre/ index_DE, last access: 01.12.2016, 2016.

Spencer, J. and Ashley, W.: Avalanche fatalities in the western United States: a comparison of three databases, Natural Hazards, doi:10.1007/s11069-010-9641-3, 2010.

Techel, F., Zweifel, B., and Winkler, K.: Analysis of avalanche risk factors in backcountry terrain based on usage frequency and accident data in Switzerland, Nat. Hazards Earth Syst. Sci., 15, 1985-1997, doi:10.5194/nhess-15-1985-2015, 2015.

Techel, F., Jarry, F., Kronthaler, G., Mitterer, S., Nairz, P., Pavšek, M., Valt, M., and Darms, G.: Avalanche fatalities in the European Alps: long-term trends and statistics, Geographica Helvetica, 71, 147-159, doi:10.5194/gh-71-147-2016, http://www.geogr-helv.net/71/147/2016/, 2016.

Valt, M. and Cianfarra, P.: 1981-2010 avalanche accidents in Italy, in: 4th International Conference on Avalanches and related subjects, September 2011, Kirovsk, Russia, pp. 94-98, 2012.

Valt, M. and Pivot, S.: Avalanche accident documentation is of fundamental importance to understand the dynamics, taking place in snow, of risky activities in order to implement the best possible prevention strategies, in: Proceedings International Snow Science Workshop 2013, Grenoble-Chamonix Mont Blanc, France, pp. 1142-1147, 2013. 
Valt, M., Chiambretti, I., and Zasso, R.: 1985 - 2009 twenty-five years of avalanche accidents in Italy, in: Proceedings International Snow Science Workshop, Davos, Switzerland, pp. 686-690, http://www.arpa.veneto.it/temi-ambientali/neve/file-e-allegati-1/05_mv_ ISSW09_paper_198.pdf, 2009.

Winkler, K.: Entwicklung des Lawinenrisikos bei Aktivitäten im freien Gelände, alpinforum, pp. 26-33, http://www.slf.ch/dienstleistungen/news/entwicklung_anzahl_lawinenopfer/ Jb2016_Final_PDF_Kurt_Winkler.pdf, 2016.

Winkler, K., Fischer, A., and Techel, F.: Avalanche risk in winter backcountry touring: status and recent trends in Switzerland, in: Proceedings International Snow Science Workshop, Breckenridge, Co., pp. 270-276, 2016.

Zeileis, A., Hornik, K., and Murrell, P.: Escaping RGBland: Selecting Colors for Statistical Graphics, Computational Statistics \& Data Analysis, 53, 3259-3270, doi:10.1016/j.csda.2008. 11.033, https://eeecon.uibk.ac.at/ zeileis/papers/Zeileis+Hornik+Murrell-2009.pdf, 2009.

Interactive comment on Nat. Hazards Earth Syst. Sci. Discuss., doi:10.5194/nhess-2016-369, 2016.

Printer-friendly version

Discussion paper 